\title{
Somatostatin in hepatocellular carcinoma: experimental and therapeutic implications
}

\author{
Elias Kouroumalis ${ }^{1}$, Demetrius Samonakis ${ }^{1,2}$, George Notas ${ }^{3}$ \\ 'Department of Gastroenterology, University of Crete Medical School, Heraklion 71003, Greece. \\ 2Department of Gastroenterology, University Hospital, Heraklion 71100, Greece. \\ ${ }^{3}$ Department of Experimental Medicine, University of Crete Medical School, Heraklion 71003, Greece.
}

Correspondence to: Dr. Elias Kouroumalis, Department of Gastroenterology, University of Crete Medical School, Heraklion 71003, Greece. E-mail: kouroumi@uoc.gr

\begin{abstract}
How to cite this article: Kouroumalis E, Samonakis D, Notas G. Somatostatin in hepatocellular carcinoma: experimental and therapeutic implications. Hepatoma Res 2018;4:34. http://dx.doi.org/10.20517/2394-5079.2018.33
\end{abstract}

Received: 31 Mar 2018 First Decision: 28 May 2018 Revised: 19 Jun 2018 Accepted: 19 Jun 2018 Published: 11 Jul 2018

Science Editor: Guang-Wen Cao Copy Editor: Jun-Yao Li Production Editor: Cai-Hong Wang

\begin{abstract}
The neuropeptide somatostatin has been shown to control the secretion of several hormones and growth factors, but also to inhibit the proliferation of several tumor cells. Hepatocellular carcinoma (HCC) is a leading cause of death all over the world due to very limited treatment modalities. Early reports showed that somatostatin may influence HCC growth, making somatostatin a potential therapeutic candidate. The introduction of somatostatin analogues with long half-lives has made this prospect feasible. In this review, experimental data regarding the presence of somatostatin receptors and their functional significance in HCC are presented. Potential mechanisms of direct anti-tumoral activity of somatostatin, including effects on tumor cell proliferation and apoptosis, inhibition of various trophic factors and angiogenesis are also reviewed, as well as indirect actions affecting liver fibrosis, inflammation and macrophage-associated innate immunity. Data on the use of somatostatin analogues for the treatment of induced HCC in experimental animals are presented and human studies of somatostatin treatment of advanced HCC are critically analyzed. Reasons and pitfalls for treatment failures are identified and indications for the proper use of somatostatin, either alone or as an adjunct to other modalities in future trials are proposed.
\end{abstract}

Keywords: Somatostatin analogues, hepatocellular carcinoma, somatostatin receptors, action mechanisms, treatment

\section{INTRODUCTION}

Hepatocellular carcinoma (HCC) is the fifth most common cancer among men and the seventh among women, with approximately 600,000 annual deaths worldwide. It is the third cause of cancer-associated

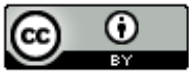

(C) The Author(s) 2018. Open Access This article is licensed under a Creative Commons Attribution 4.0 International License (https://creativecommons.org/licenses/by/4.0/), which permits unrestricted use, sharing, adaptation, distribution and reproduction in any medium or format, for any purpose, even commercially, as long as you give appropriate credit to the original author(s) and the source, provide a link to the Creative Commons license, and indicate if changes were made.

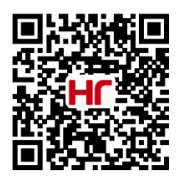


death, after cancers of stomach and lung. HCC global incidence varies usually following the distribution of hepatitis B or C viruses. It is highest in China, eastern Asia and Africa (20-35 per 100,000 population) and low $(<5$ per 100,000) in Northern Europe and the USA. Mediterranean and eastern European countries have an intermediate rate of 10-20 per 100,000 population $^{[1-3]}$.

In 1968, a hormone secretion inhibitory molecule was described, later cloned and named somatostatin ${ }^{[4]}$. The somatostatin (SST) protein has two active forms created by alternative cleavage of a single pre-protein: the 14 amino acids SST14 and the 28 amino acids SST28, different only in potency but not in function ${ }^{[5]}$. It soon became obvious that SST had many potential therapeutic implications but the natural molecules had the inherent drawback of a very short half-life (less than $3 \mathrm{~min}$ ) that made in vitro and in vivo applications very difficult. Therefore somatostatin analogues (SSA), namely octreotide, vapreotide, lanreotide and pasireotide were later synthesized to overcome the difficulty ${ }^{[6-8]}$.

Extensive research resulted in identification and cloning of five somatostatin receptor (SSTR) subtypes (SSTR1- SSTR5) with two splice variants (SSTR2A and SSTR2B) for SST2. They are a family of transmembrane G-protein-coupled receptors and are encoded by separate genes on different chromosomes. All five receptors bind natural SST14 and SST28 with a high affinity. The synthetic analogues bind to some but not all receptors with varying affinity. Octreotide and Lanreotide have a binding affinity only for SST2 and SST5 while pasireotide binds to all receptors with the exception of SST4 ${ }^{[9,10]}$.

Several intracellular pathways are activated after binding SST or its analogues to the receptors leading to down-stream signaling and modulation of adenylyl cyclase (AC) (SSTRs 1-5), phosphotyrosine phosphatases (PTPs) (SSTRs 1-3) and mitogen activated protein kinase (MAPK) (SSTR4), as well as calcium and potassium channels and the sodium-proton antiporter ${ }^{[6,9,11-13]}$.

Research data have made clear that somatostatin has several antineoplastic actions and could be used in clinical applications in various human cancers ${ }^{[14]}$, including HCC. An extensive review has been recently published ${ }^{[10]}$. The present report will therefore summarize both experimental and clinical data on the use of SST and SSA in HCC.

\section{EXPERIMENTAL DATA}

There are many reports providing strong evidence that somatostatin may have an effect on HCC. Research is focused on the variability of SSTRs present in isolated cells and liver tissue, but also on functional aspects of the activation of these receptors.

\section{SST receptors in liver cells}

Hepatoma cells

Hep G2 cells are the most widely used human hepatoma cell line in liver research. The presence of mRNA of only 2, 3 and 4 SSTR subtypes was demonstrated in these cells by Northern blotting ${ }^{[15]}$ but inconsistent results have been reported.

Another report found that cultured HepG2 cells expressed all five SSTRs, at both the protein and mRNA levels, while $\mathrm{HuH} 7$ hepatoma cells lack SSTR $3^{[16]}$. Using immunohistochemical staining, HepG2 cells were reported to display weak expression of SSTR2 and moderate levels of SSTR5. Hep3B cells showed weak expression of SSTR3 and strong SSTR2 and SSTR5 staining while HuH7 cells additionally stained positive also for SSTR1, but not SSTR $3^{[17]}$.

Our laboratory reported that HepG2 cells were found to express SSTR2, SSTR3 and SSTR5 receptors by RT-PCR. All these SSTRs were shown to have a mainly intracellular distribution with different individual 
distribution patterns. Membrane binding sites for SST were mainly of the SSTR3 and SSTR5 types, with a weak SSTR2 binding ${ }^{[18]}$. Later, we demonstrated the presence of SSTR2 and SSTR5 in another hepatoma cell line, the Hep3B cells ${ }^{[19]}$. Importantly we have also demonstrated that HepG2 cells express cortistatin and we attributed the SSTRs internalization to the endogenous production of cortistatin ${ }^{[18]}$. Cortistatin is a 17-aminoacid peptide with high affinity to all somatostatin receptor subtypes ${ }^{[20]}$. Internalization of SST2 receptors after octreotide administration has also been reported in neuroendocrine tumors ${ }^{[21]}$.

\section{Liver stellate cells (HSCs)}

Activated rat hepatic stellate cells were reported to express SSTR subtypes 1, 2, and $3^{[2]}$, while another report found all five SSTRs in HSCs, at both the protein and mRNA level ${ }^{[16]}$. Using a different approach, the expression of SSTR2, SSTR3 and SSTR5, but not SSTR1 and SSTR4, was demonstrated by confocal microscopy in rat HSCs. The mRNA expression level of SSTR2 was much higher than the other subtypes ${ }^{[23]}$.

We have recently shown that quiescent HSCs (day 0 or day 3) do not express SSTRs by immunocytochemistry or western blot. However at day 7, SSTRs 1, 2A, 2B, 3 and 4 started to appear in some cells activated by adherence to plastic but only after day 10, all cells were positive for SSTRs 1, 2A, 2B, 3 and 4 . Therefore, whatever the effect of somatostatin might be on these cells, it is not evident from the beginning of any experiment ${ }^{[24]}$.

\section{Kupffer cells}

In contrast to HSCs, quiescent rat Kupffer cells were shown to express mRNA of SSTR 1-4. However immunocytochemistry identified only the presence of internalized SSTR 3 and SSTR4 receptors. Western blotting on the other hand detected SSTR2 and SSTR2a. Thus it seems that in quiescent cells the detection of SSTRs depends on the method used. Moreover Kupffer cells were found to express both somatostatin and cortistatin, a finding that may explain the internalized receptors. Stimulation of the cells with lipopolysacharide activated the expression of SSTR2, SSTR3 and SST4 ${ }^{[25,26]}$.

\section{SST receptors in HCC tissue}

Somatostatin receptors were identified in $41 \%$ of HCC in an earlier report on the presence of regulatory peptides receptors in HCC. These receptors showed high affinity for both natural somatostatin and octreotide $^{[27]}$. This observation was verified and further extended. Cirrhotic livers and HCC expressed all five SSTRs both at the protein and mRNA levels, but normal livers were negative for all SSTRs ${ }^{[16]}$. Moreover, it seems that all HCCs do not display similar expression patterns for SSTRs. Expression rates as high as 75\% for SSTR5 and as low as 41\% for SSTR2 were demonstrated while SSTR4 was absent. There was no correlation between SSTR expression and tumor stage or underlying liver disease ${ }^{[28]}$. Higher overall rates of all SST receptors were reported in both HCC and cirrhosis in a report from China. In contrast with the previous study, high expression of SSTR4 was also identified. The protein levels of receptors were markedly higher in HCC than in cirrhosis. Moreover there was a strong correlation of all receptors with serum AFP levels ${ }^{[2]}$. A high $67 \%$ expression of SSTR2 was also shown but there was no correlation with tumor molecular characteristics including tumor suppressor genes ${ }^{[30]}$. Very high expressions of SSTR1 and SSTR 5 were also reported in a recent study of 41 liver biopsies ${ }^{[31]}$.

On the contrary, a recent report from Germany found very low overall rates (8\%-15\%) of weak SSTRs expression in the tissue of patients with either cirrhosis or HCC. It should be stressed however that all but two of their patients had alcohol-related disease. This is important when therapeutic implications are concerned ${ }^{[17]}$.

Thus, the available literature indicates variable expression of SSTR subtypes in both hepatoma cell lines and liver tissue from cirrhotic and HCC patients. This may be due to different methodologies, different etiologies of cirrhosis and HCC or different molecular events leading to HCC. Nonetheless SSTRs are expressed in a significant proportion of HCC and may therefore be a potential therapeutic target. This is further supported by functional data. 


\section{Functional data}

Early preclinical studies have demonstrated that both natural SST and its synthetic analogues exert an anti-proliferative effect in hepatoma cell lines ${ }^{[32,33]}$. In addition to proliferation, SSAs were shown not only to decrease cells in the S-phase but most importantly to induce apoptosis in a dose-dependent manner in HepG2 cells ${ }^{[15]}$. These effects on proliferation and apoptosis were verified and correlated with the presence of SST receptors in HCC cell lines. Apoptosis was significantly lower in normal hepatocytes ${ }^{[34]}$.

In contrast with these studies, no influence of SSAs on either proliferation or apoptosis could be identified in another study. However the migration of hepatoma cells (HepG2 and $\mathrm{HuH} 7$ ) was significantly reduced after incubation with a selective SSTR1 agonist in Boyden invasion chambers. These findings may indicate a reduced invasive capability of hepatoma cells attributable to the presence of SSTR $1^{[16]}$.

Negative results on proliferation and apoptosis were also verified using a different cell line. Short-term octreotide treatment of Bel-7402 cells did not affect cell proliferation and apoptosis. The SSTR2 protein level was significantly decreased after exposure to octreotide ${ }^{[35]}$. Different results were very recently obtained using the same Bel-7402 cells. All SSAs tested increased cellular apoptosis but had no effect on cellular proliferation while the effect on SSTRs expression was variable ${ }^{[36]}$.

However in vivo experimental data have demonstrated that SST significantly inhibits tumor proliferation. The same investigators, have convincingly shown that long-term SSA treatment effectively inhibited the development and growth of HCC and improved survival rates, possibly through resensitization and upregulation of SSTR2 and SSTR $5^{[3,36]}$.

A very interesting observation was reported by Xie et al. ${ }^{[37]}$. While octreotide significantly enhanced apoptosis on HepG2, no such response was observed in HepG2 cells transfected with the HBV X gene. Moreover the expression of SSTR2 and SSTR5 was reduced in these cells. This may have therapeutic implications.

The role of HSCs/myofibroblasts in HCC has not been extensively investigated but early studies indicate that they favor tumor progression producing hepatocyte growth factor ${ }^{[38,39]}$. SST or its SSAs have been reported to influence hepatic stellate cells and indirectly the progress of HCC. Thus SST at nanomolar concentrations was found to decrease rat HSC proliferation and increase apoptosis ${ }^{[40]}$.

SST caused a significant decrease of collagens I and III production by activated rat HSCs without reduction of cell proliferation thus implicating a direct action of somatostatin on $\mathrm{HSC}^{[41]}$.

The effect of octreotide on cellular proliferation of isolated rat hepatic stellate cells was recently investigated in our lab. The drug had no effect on proliferation but strongly inhibited procollagen production from activated stellate cells. It also inhibited PDFG and TGFb1 dependent procollagen production probably through activation of phosphotyrosine phosphatase (PTP) and phosphoserine-phosphothreonine phosphatase (STP) ${ }^{[24]}$.

\section{Mode of action}

Octreotide is effective in inhibiting growth of HCC in vivo and in vitro ${ }^{[42]}$. There are several potential mechanisms through which SST and SSAs might inhibit HCC progress.

\section{Cell proliferation and apoptosis}

Despite the negative results mentioned before it is accepted today that SST and SSAs have a direct antiproliferative effect on cancer cells via specific SSTRs. SSTRs 1, 4 and 5 modulate the MAP kinase pathway and induce G1 cell cycle arrest ${ }^{[43]}$. However, the cell cycle arrest mechanisms depend on the SSTR 
subtypes involved and are not similar to all cell types. SSTR1 acts through the stimulation of the tyrosine phosphatase SHP-2, activation of the MAP kinase ERK pathway and induction of the p21Waf1:Cip1 ${ }^{[44]}$, while the SSTR5 acts through inhibition of guanylate cyclase, and MAP kinase ERK ${ }^{[45]}$. The cytostatic role of the SSTR2 has been connected to the modulation of ERK1/2 signaling pathway ${ }^{[46]}$ and the activation of the phosphotyrosine phosphatases (PTPs) SHP-1, SHP-2 and PTP $\eta$. SHP-1 induces proapoptoptic caspasemediated signals and also causes apoptosis by activation of the NF- $\kappa B$ leading to the inhibition of the JNK anti-apoptotic effects. Activation of PTP $\eta$, dephosphorylates intracellular effectors such as the ERK and the PI3K/Akt pathways leading to upregulation of the cyclin kinase inhibitors p21cip1/waf1 and p27kip1. Cells are therefore accumulated in the G1 phase and cell proliferation is blocked ${ }^{[8,47]}$. pERK1/2 was inhibited in response to natural SST while receptor-specific agonist treatment caused a dual effect: inhibition at lower concentrations and activation at higher concentrations ${ }^{[48]}$.

Earlier studies also pointed out that SSTR2, but not SSTR3, mediated induction of cyclin-dependent kinase inhibitors p21 and p27Kip1 leading to cell cycle arrest ${ }^{[49]}$. However, a recent report has shown that SSTR2 and SSTR3 co-expression strongly induced p21 and p27Kip1 expression and therefore had a cytostatic effect ${ }^{[48]}$.

Inherent to the anti-proliferative effect of SST is the induction of apoptosis whether dependent or independent of $553^{[34,50,51]}$. Apoptosis induction is mediated by either the SSTR2 activation or the co-expression and heterodimerization of SSTR2 and SSTR $3^{[48,52]}$.

Caspase-mediated signaling pathways of octreotide antitumor activity in HepG2 cells were also reported from our lab. We have observed an interesting phenomenon that may have therapeutic implications. Measuring activities of various caspases and apoptosis in HepG2 cells we found that octreotide decreased proliferation only at concentrations of $10^{-8} \mathrm{~mol} / \mathrm{L}$, while lower concentrations increased proliferation, indicating that measurements of serum octreotide levels may be important, at least in clinical trials, to verify optimal therapeutic drug concentrations ${ }^{[53]}$.

There are additional molecular pathways through which SST and SSAs increase apoptosis in a time and dose dependent manner in human hepatoma cells. Thus, they were found to increase expression rates of the FasFas ligand system leading to apoptosis ${ }^{[54]}$.

Another intriguing mechanism is the facilitation of apoptosis by endogenous opioids. We have demonstrated in HepG2 cells that opioids inhibit proliferation and induce apoptosis. Since functional opioid receptors were not found on HepG2 cells we demonstrated that opioids bind to somatostatin receptors activating a PTP signaling cascade ${ }^{[55]}$. Interestingly, a native functional endogenous opioid system was recently described. Opioid growth factor (OGF) and its receptor were identified in hepatoma cell lines and in specimens from HCC. OGF inhibited tumor cell replication by inhibition of DNA synthesis without interfering with apoptosis ${ }^{[5]}$.

Direct or indirect inhibition of various trophic factors associated with the progress of HCC

One of the most important systems involved in tumor progression is the growth hormone-insulin-like growth factor-somatostatin (GH-IGF-SST) system. Several components of this system have been shown to be regulators of hepatocarcinogenesis ${ }^{[57-59]}$. In particular over-expression of IGF1 receptor and decrease of IGF-binding proteins have been described in patients with HCC and hepatoma cell lines. Interestingly an increase of cathepsin D, an acid serum protease that cleaves IGF binding proteins, has also been described in HCC $^{[0,61]}$. Many studies have evaluated the relation between increased levels of IGF1 receptors and liver diseases and the oncogenic role of IGF2 and its implication in angiogenesis, migration and, consequently, in tumor progression ${ }^{[62]}$. 
Pasireotide, a somatostatin analogue with high affinity for all SSTRs except SSTR4, is a more potent inhibitor of IGF1 than octreotide ${ }^{[63]}$. It is noteworthy that the GH-IGF system is connected with the important role of Raf/MEK/ERK, one of the signaling cascades stimulated by IGF1R in experimentally induced apoptosis of hepatoma cell lines and possibly explains why the Ras gene is activated in $30 \%$ of $\mathrm{HCCs}^{[64]}$ while its substrate RAF kinase is over-expressed in many $\mathrm{HCCs}^{[65]}$. The same pathway is activated by other growth factors known to be over-expressed in HCC like PDGF, EGF and TGFa ${ }^{[6,66]}$.

SST also inhibits the secretion of other hormones (gastrin, glucagon, insulin) which have been shown to be trophic factors for cancer cells but their significance in hepatocellular carcinoma evolution has not been elucidated ${ }^{[7,68]}$.

\section{Direct inhibition in vivo and in vitro of angiogenesis}

Neo-angiogenesis is a vital process allowing tumors to grow and metastasize ${ }^{[69]}$. The SSA octreotide was able to inhibit angiogenesis induced by HCC in vivo ${ }^{[70]}$. In nude mice with an implanted hepatocellular carcinoma, octreotide showed a strong anti-angiogenic activity ${ }^{[7]}$. Available evidence suggests that SSAs inhibit angiogenesis either directly through somatostatin receptors on endothelial cells or indirectly through the inhibition of vascular endothelial growth factor (VEGF) or via inhibition of adenylyl cyclase ${ }^{[7,72,73]}$. Recently, a combination of celecoxib and octreotide was found to have a potent anti-angiogenetic activity by decreasing the phosphorylation of the integrated signaling pathways of p-ERK kinase-HIF-1a (hypoxiainducible factor-1a)-VEGF ${ }^{[74]}$. This combination has been tried in hepatocellular carcinoma as analyzed in the relevant section.

\section{Antineoplastic effect via immune modification - innate immunity}

SST and SSAs may exert an anti-tumor activity through modulation of immune pathways. More data are required in this field ${ }^{[75-77]}$. Many studies have been focused on the effects of somatostatin on the innate component of immunity and in particular on inflammation and oxidative stress. Reduced secretion of reactive oxygen species by macrophages after incubation with SST has been reported ${ }^{[88]}$. More specifically for the liver, the amount of hydrogen peroxide released by Kupffer cells treated with SST was reduced compared to controls. Moreover SST also reduced production of nitric oxide and TNFa by Kupffer cells ${ }^{[79]}$.

We have verified that octreotide reduces TNFa and NO production by Kupffer cells decreasing iNOS activity probably through an interference with phosphatidylinositol 3-kinase pathways. Like most, if not all cancers, HCC has an inflammatory component. SST may therefore inhibit the growth of HCC by reducing inflammation. In this respect we showed that rat Kupffer cells treated with octreotide produced reduced amounts of the pro-inflammatory cytokine IL-12 and increased amounts of the antiinflammatory IL-13 ${ }^{[80]}$.

Macrophages are deeply involved in HCC pathogenesis through other mechanisms as well. Myeloid cells, including tumor-associated macrophages (TAMs) have been identified in large numbers in HCC microenvironment and are often associated with poor prognosis ${ }^{[81,82]}$.

During induction of HCC, there is an increased production of IL- 6 and TGFb1 by macrophages leading to activation of STAT3 and progression of the tumor ${ }^{[83]}$. At the same time, predominant activation of STAT3 leads to an M2 macrophage polarization ${ }^{[84]}$. M2 cells are involved in polarized Th2 responses and to tumor progression and immunoregulation ${ }^{[82]}$. TGFb1 production by Kupffer cells is reduced by octreotide in vitro, therefore the polarization of liver resident macrophages towards the M2 phenotype may be reduced as well ${ }^{[85]}$. We have also proposed that the antitumor effect of octreotide in HCC may in part be explained by its antiapoptotic effect on Kupffer cells. Using caspase3 mRNA as an index of apoptosis, we measured pro-and antiapoptotic molecules in Kupffer cells after incubation with octreotide. The increased apoptosis of cultured 
Kupffer cells was reversed by octreotide as a down-regulation of pro-apoptotic and an early increase of antiapoptotic molecules were demonstrated ${ }^{[s]}$.

Another important function of liver associated macrophages is mediated through the production of chemokines and their actions on their receptors. The co-operation of CCR 2 bearing macrophages and T cells results in the clearance of senescent hepatocytes, thus preventing HCC development. In case of established HCC, however, recruitment of CCR2 positive macrophages leads to accumulation of suppressive TAMs resulting in tumor progression due to the inhibition of CD8 $\mathrm{T}$ lymphocytes and natural killer cells ${ }^{[86]}$. CCL2 is highly expressed and is a prognostic factor in HCC. Inhibition of CCL2/CCR2 signaling suppressed liver tumor in experimental animals through activation of $\mathrm{T}$ cell anti-tumor response as expected ${ }^{[87]}$.

CC chemokines and particularly CCL2 (MCP-1) are also involved in the progression of liver fibrosis ${ }^{[88]}$. Kupffer cells were shown to secrete large amounts of CC chemokines (MCP-1, Rantes) and CXC chemokines (IL-8, MIP-2) after LPS stimulation. Octreotide inhibited only CC chemokines but not CXC chemokine secretion, an effect mediated by PI3-kinase. Therefore inhibition by octreotide of CC chemokines and specifically MCP-1 will lead to reduced HCC growth both directly inhibiting the accumulation of tumor suppressive macrophages and indirectly reducing fibrosis. Whether modifications of macrophage microenvironment influence HCC progression remains to be elucidated ${ }^{[89]}$.

Strictly speaking, although hepatic stellate cells are not members of the innate immune system, they may participate in inflammation producing pro-inflammatory molecules ${ }^{[90,91]}$. Somatostatin inhibited the secretion of the pro-inflammatory cytokines IL-1beta and IL-8 from rat liver stellate cells ${ }^{[92]}$.

\section{Indirect anti-neoplastic effect through modulation of fibrosis}

Most HCCs are developed in a cirrhotic background. As mentioned before, SST has a profound effect on hepatic stellate cells reducing collagen I and III production and also procollagen production through activation of phosphotyrosine (PTP) and phosphoserine-phosphothreonine (STP) phosphatases without affecting stellate cell proliferation. A direct action of SST on stellate cells has been proposed ${ }^{[16,21]}$.

Moreover SST may influence fibrosis through its action on Kupffer cells augmenting matrix degradation. Kupffer cells produce large amounts of MMP1 (the enzyme responsible for native collagen degradation), and lipopolysaccharide activation induces a significant early increased production of MMP1. Octreotide had a synergistic effect with lipopolysaccharide on MMP1 secretion. In addition lipopolysaccharide and octreotide, alone or in combination, induced a significant inhibition of the large amounts of TGF-b1 produced by unstimulated Kupffer cells. Inhibition of TGFb1 implied that SST may also indirectly influence stellate cells and liver fibrosis ${ }^{[93]}$. Some of the anti-tumoral actions of SST have been reviewed ${ }^{[94,95]}$. Figure 1 summarizes the cellular pathways of SST actions in HCC.

\section{In vivo animal data}

In an earlier report, HCCs were developed after implantation of Morris hepatoma cells in rats. Partial hepatectomy enhanced tumor progress, but treatment with octreotide inhibited the growth of the tumor ${ }^{[96]}$. Similarly octreotide was shown to inhibit liver regeneration after partial hepatectomy ${ }^{[97]}$.

Subsequent studies from China have corroborated these results using the nude mice HCC xenograft model and octreotide administration. Tumor weights were significantly reduced, the growth was inhibited and secondary primaries and lung metastases were also decreased. More importantly, survival of the treated animals was significantly prolonged ${ }^{[98,99]}$. Recent studies reported on the effect of a combination of a COX 2 inhibitor with an SSA. They have demonstrated that the combination had an anti proliferative effect but most importantly it suppressed the metastasis of HCC in nude mice ${ }^{[100]}$. Moreover the same combination 


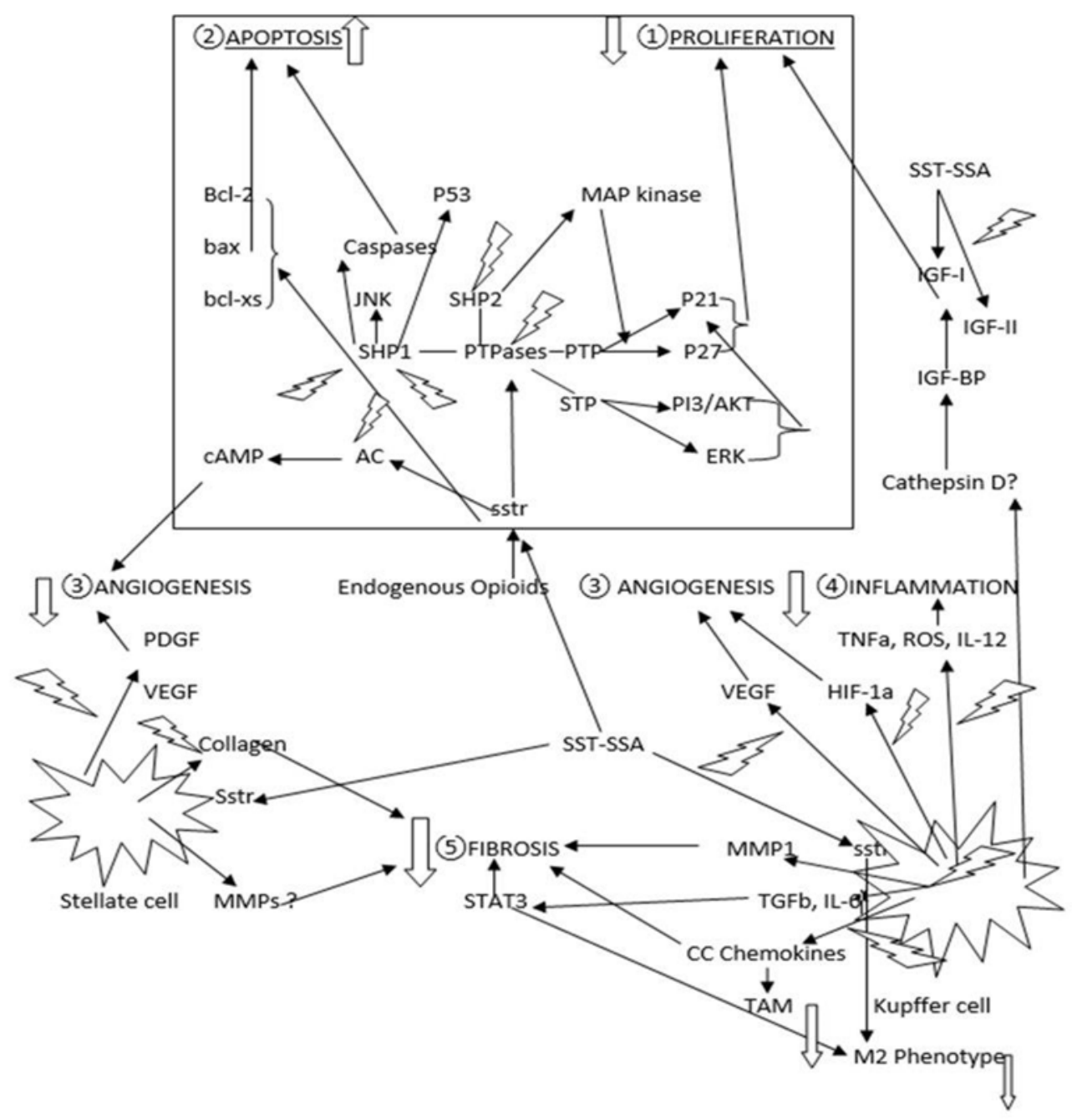

Figure 1. Anti-tumoral effect of somatostatin is achieved through various cellular pathways leading to inhibition of cell proliferation, inflammation, fibrosis and angiogenesis. Apoptosis is increased. It seems that a reduction of tumor associated macrophages (TAM) and a swift from M2 polarization in Kupffer cells may also help in the final effect

significantly prolonged the survival of rabbits with experimental liver cancer previously treated with tumor arterial embolization $(\mathrm{TAE})^{[101]}$. Treatment with octreotide and celecoxib after TAE, synergistically inhibits hepatic allograft metastasis by promoting tumor encapsulation and inhibition of angiogenesis ${ }^{[102]}$.

Lanreotide, a long acting SSA, was used as a cancer chemopreventive agent in a series of animal experiments. Thus, lanreotide was able to decrease the size of diethyl- nitrosamine induced liver preneoplastic foci by inhibiting cell proliferation and increasing apoptosis. This was associated with a decrease of cyclin D1 and an increase of p27kip $1^{[103]}$. Lanreotide also reduced the number of chemically induced HCCs and significantly decreased fibrosis and the level of angiogenic factors ${ }^{[104,105]}$. In another animal model, albino mice developed HCC by injection with diethyl-nitrosamine. The administration of octreotide alone or in combination with a plant extract prevented malignant transformation. This effect was associated with a substantial reduction of oxidative stress observed in the control animals ${ }^{[106]}$.

A rather intriguing finding was recently reported in rats with a high fat diet induced obesity. Octreotide increased hepatic glucogenesis associated with increased glucose synthase and decreased fasting blood 
glucose. More importantly, octreotide significantly reduced liver steatosis in obese rats. If confirmed, these results may justify the use of octreotide as a preventive measure of HCC in non alcoholic fatty liver disease ${ }^{[107]}$.

These experimental preclinical data indicating anti-proliferative and anti-metastatic effects of SSAs in HCC, supported the initiation of clinical studies in patients with HCC.

\section{CLINICAL DATA}

\section{Favorable data}

For the first time octreotide was used for HCC treatment by our group in a randomized controlled trial of 58 mostly Okuda II and III patients. Subcutaneous octreotide almost doubled survival while treated patients clearly had a lower hazard of death (0.383), in the multivariate analysis.

We confirmed these results later in a non randomized trial with long-acting analogues where the relative risk of death of the untreated patients was 2.7 (95\% CI: 1.4-5.3) compared to the treated patients. Approximately $40 \%$ of tumors either regressed (10\%) or remained stable $(30 \%)$, a figure similar to the overall reported expression of somatostatin receptors as mentioned before. Moreover patients retained their appetite, a satisfactory body weight and sense of well being even if tumors were radiologically progressing. The etiology

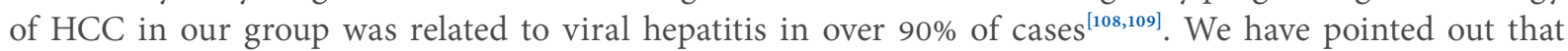
somatostatin is not a rescue drug and the survival benefit is significant in the Kaplan-Meier survival curves only after 6 months of treatment. Moreover we observed that HCCs whose etiology was alcoholic cirrhosis were less responsive, particularly in patients who continued drinking ${ }^{[18]}$.

In an uncontrolled study of 21 patients, lanreotide caused a $43 \%$ response, similar to ours (one tumour regressed and 8 were stable, despite the fact that no patient had SSTRs on octreotide scintigraphy). Five patients $(24 \%)$ had a decrease in serum-AFP levels by at least $30 \%{ }^{[15]}$. A similar uncontrolled study of mostly viral HCC cases reported that octreotide improved survival time in non-cirrhotic patients. It should be noted however that $40 \%$ of the cirrhotics were Child Pugh C stage and that most of them died before 6 months ${ }^{[110]}$.

Another Greek group also reported that octreotide doubled survival in a randomized trial of patients with HBV or HCV related HCC who had detectable SSTRs on 111Indium octreotide scintigraphy. By contrast SSTRs negative patients had no survival benefit. Again the Kaplan-Meier curve showed that the benefit was significant after approximately 6 months of treatment ${ }^{[111]}$.

In a controlled trial from China, a combination of tamoxifen and octreotide was compared to conventional chemotherapy. In the octreotide arm, a complete response or partial response was found in $43 \%$ of patients and survival was also doubled compared to chemotherapy ${ }^{[112]}$.

A controlled study from Pakistan in reported tumor regression in $45.4 \%$ of patients with HCV related HCC, while alpha fetoprotein reduction was noticed in 50\%. Significant survival benefit and improvement of quality of life were also found ${ }^{[113]}$. A seemingly negative small observational study on patients with advanced HCC has been reported from the USA. The median survival was only 4.5 months. However, 6/22 patients (27\%) survived for more than 10 months and most interestingly these were patients of Asian descent with a history of HBV infection ${ }^{[114]}$.

In a retrospective controlled study of 95 patients on octreotide (57\% viral etiology and $43 \%$ alcoholics), survival rates of patients with Barcelona classification stage B were significantly higher (22.4 months), 
compared to patients who received palliative care only (2.9 months). Patients with BCLC stage A had also higher survival (31.4 months) compared to palliative care (15.1 months) but this was not significant due to small number of patients in this group ${ }^{[115]}$.

In addition to these data there have been two case reports of HCC patients of viral etiology who responded with complete regression of the tumor with either lanreotide or long-acting octreotide ${ }^{[116,117]}$. Recently a case of HBV-associated HCC with SSTR2 overexpression and metastases in the lung and mediastinal lymph nodes detected 17 months after left hepatectomy was described. Treatment with lanreotide $30 \mathrm{mg}$ twice a month resulted in a significant size reduction of the mediastinal nodes and complete disappearance of the lung nodes. This objective response lasted for 42 months $^{[118]}$.

A randomized study of fairly advanced HCC compared treatment with either octreotide alone or in combination with rofecoxib. Survival in both groups was significantly associated with baseline serum VEGF and IGF1 levels ${ }^{[119]}$.

Two large recent trials from China highlighted the significance of the presence of SSTR2 and SSTR 5 for the response to SSAs. Importantly these were studies on early-stage HCC and treatment was administered after resection of the primary tumor. In the study by Li et al. ${ }^{[120]}, 76$ patients with operable HBV-related HCC were divided into two groups according to SSTR2 and 5 expression profiles. The mean survival time was longer in the high SSTR2/5 expression group. Similar results were reported in another study of 99 HBV-related HCC. Recurrence rate and survival were significantly higher in patients with high expression of SSTR ${ }^{[121]}$. Both studies concluded that the expression profile of SSTRs can be used as an independent prognostic factor.

There have been interesting results when SSAs were compared to transarterial chemoembolization (TACE) or radiofrequency ablation (RAF) or were given in combination with TACE or sorafenib.

In an earlier report of a prospective non-randomized study from Germany, 41 patients were treated with octreotide and compared for survival to another group of patients treated with TACE. A median survival of 571 days was found in the octreotide group, similar to the TACE group ${ }^{[122]}$. This was confirmed later in a larger randomized trial where, octreotide treatment had a similar outcome compared to patients who received TACE or multimodal therapy ${ }^{[115]}$.

In an observational study, a combined approach of RAF followed by octreotide was adopted for treatment of viral-associated HCCs, mostly Child A and Child B ( $60 \%$ and $34 \%$ respectively). All patients had multiple liver HCC nodules; $14 \%$ had complete or partial tumor regression and a clinical benefit was evident in $80 \%$. Mean survival was 31.4 months. Serum VEGF was significantly correlated with response ${ }^{[123]}$.

In a different setting, 147 patients diagnosed with HCC suitable for TACE received 2-4 TACE procedures; 84 patients received an additional heparin plus octreotide combination and 63 patients were given only heparin and served as the controls without randomization. They reported a significant reduction in the incidence of tumor metastasis within a year of follow-up post-TACE, in the combination treatment ${ }^{[124]}$.

In a recent randomized study from China, 71 patients with mostly viral associated HCC, BCLC stages B and C were assigned to either TACE $(n=35)$ or TACE plus celecoxib plus octreotide $(n=36)$ and were followed up for 3 years. The median overall survival of the TACE $+\mathrm{C}+\mathrm{L}$ group of 15.0 months was twice as much compared to that of the TACE group ( 7.5 months) and the survival benefit was very significant for both BCLC stage B or C. Equally significant was the improvement in the quality of life in favor of octreotide. Post-embolization syndrome was also significantly lower in the octreotide group ${ }^{[125]}$. 
The results of the combination of octreotide plus sorafenib were reported in a prospective non controlled phase II study of advanced viral associated HCC (mostly HCV), Child-Pugh A or B; 10\% of patients achieved partial response and $66 \%$ had stable disease with a median survival of 12 months. The combination was well tolerated $^{[126]}$.

Further work from the same group has shown that responders had a significant decrease of reactive oxygen species in the peripheral blood mononuclear cells and this reduction was enhanced when octreotide was added to sorafenib. A 50\% pERK activity reduction was observed in responders compared to an $80 \%$ increase in non responders. Sorafenib induced a $40 \%$ increase in serum NO and this was further increased after octreotide ${ }^{[127]}$. Whether SSAs offer any advantage as an addition to sorafenib remains to be established.

\section{Unfavorable data}

A retrospective observational non controlled study found no evidence of survival benefit in 63 patients $\left(40 \%\right.$ alcoholics ${ }^{[128]}$. The first negative randomized controlled study was reported by Yuen et al. ${ }^{[129]}$. It has been heavily criticized by us and many others, because the selected patients had a very short survival of 1.9 months in the control group $(n=35)$ vs. 2 months in the octreotide group $(n=35)$ indicating that most patients belonged to BCLC stage $\mathrm{D}$. In fact 21/35 patients received either none or just one long-acting octreotide injection ${ }^{[130]}$.

A non-randomized subsequent study found limited beneficial response after octreotide administration. However, 4 patients $(6 \%)$ did not receive any octreotide because their disease progressed so rapidly they were unable to start treatment. These patients were included in the survival analysis; 5\% received 1 dose, 19\% 2 doses, $16 \% 3$ doses and 16\% 4 doses. Additionally, from the 30 patients surveyed, 6 were not enrolled due to intolerance to the test dose. The selection of patients also raises some questions. A significant number (50\%) had vascular thrombosis (extent is not specified) and $13 \%$ had metastatic disease. It should be noted that among the 14 patients who received treatment of more than 3 months, 50\% were judged to be stable, which is in accordance to virtually all previous results ${ }^{[131,132]}$.

Another open-label study of 63 patients (22\% alcoholics) reported little anti-cancer activity and a median survival of 8 months. However, the reason for stopping treatment was disease progression or toxicity and therefore assessment of survival was not really feasible $e^{[133]}$.

A randomized controlled study compared the effect of tamoxifen (control group) with tamoxifen plus octreotide in 109 patients (52.4\% alcoholics) and reported no survival benefit. Again the median survival of the treatment group was only 3 months and $44 \%$ of patients received only $1-3$ injections. Moreover the median survival in Child-Pugh A patients was only 6 months ${ }^{[134]}$.

The HECTOR study, a randomized double-blind placebo-controlled multicenter trial of 120 patients, showed no survival benefit for octreotide compared to placebo, with a median survival of 4.7 and 5.3 months respectively. Quality of life was also unaffected. However $52 \%$ of the treatment group had alcoholic cirrhosis and at 6 months the survival rate was only $40 \%{ }^{[135]}$.

Similarly negative were the results from another multicenter randomized placebo controlled study. But again $50 \%$ of the randomized patients had alcoholic cirrhosis ${ }^{[136]}$. A recent everolimus plus pasireotide open-label study of 26 patients (BCLC stage C $88 \%$, and $>60 \%$ alcoholics) also gave negative results with a median survival of 6.7 months. However the reason for treatment discontinuation was disease progression and not death. Treatment was administered for only a median of two 28-day cycles. Yet, 10/22 evaluable patients had stable disease as best response ${ }^{[137]}$. 
A seemingly not favorable open label trial of twenty patients (all HBV or HCV) treated with pasireotide was recently reported. $90 \%$ had prior therapy, $75 \%$ had BCLC stage C, and 55\% had metastatic disease. Despite this, a stable disease in 9 patients was demonstrated (45\%), and the median survival was 9 months ${ }^{[138]}$.

The situation is possibly clarified from a Chinese meta-analysis of approximately 800 patients from 9 trials. The 6-and 12-month survival rates in the octreotide group were significantly higher than those of the control group (6-month: RR 1.41, 95\% CI: 1.12-1.77, $P=0.003$; 12-month: RR 2.66, 95\% CI: $1.30-5.44, P=0.008$ ) but this was not the case when only western studies were analyzed ${ }^{[139]}$. This meta-analysis vividly describes that there is a discrepancy in results between China (and in that regard Greece) and Western countries. This is also evident from the analysis presented in this review.

One possible explanation for the negative results is the tachyphylaxis through which SSTRs are internalized upon prolonged exposure of tumors to somatostatin analogues. However there is evidence that resensitization may occur ${ }^{[35]}$. In addition the expression profile of receptors is variable among tumors. Also production of endogenous cortistatin may further affect the expression and internalization of the receptors ${ }^{[95]}$.

Serum levels of octreotide may also be a critical parameter in HCC response. As mentioned before octreotide decreased proliferation only at concentrations of $10^{-8} \mathrm{~mol} / \mathrm{L}$, while lower concentrations increased proliferation, making drug serum levels an important parameter at least in clinical trials ${ }^{[53]}$. However, these possible resistance mechanisms cannot explain the differences between the East (and Greece) and the West.

A critical evaluation of the reported studies offers potential explanations for the discrepancies. First, as we pointed out, the survival benefit is evident only in patients that live long enough to have a treatment period of more than 6 months. Somatostatin is not a magic bullet and the potential molecular pathways of its action require some time to produce measurable results. The second explanation is very important. Practically all negative western studies recruited a large number of alcoholic cirrhosis (between 25\% and 60\%) reflecting the etiological background of their population. In contrast, Chinese studies have almost exclusively recruited viral cirrhosis in accordance with cirrhosis etiology in their population. The same was true in the original Greek studies. It was our impression that our few alcoholics did not respond equally well to somatostatin particular those that do not abstain from alcohol. This critical point is not mentioned in any of the negative papers. As mentioned before, a very recent report from Germany found very low rates of weak expression of SSTRs in liver tissue from alcohol related HCC patients ${ }^{[17]}$. Only two of their patients had virus-related HCC.

\section{CONCLUSION}

Selection of patients is critical in any study of HCC treatment ${ }^{[18,130,132]}$. It seems that SST is suitable for patients with viral cirrhosis ideally after identification of the expression on the tumor of SSTR2 and 5, either with scintigraphy or even better by immunofluorescence after a liver biopsy. Eligible patients are those classified as BCLC stage $\mathrm{B}$ or $\mathrm{C}^{[140]}$ which is the same indication with TACE and possibly sorafenib. Patients with alcoholic cirrhosis-related HCC may be treated as those in BCLC stage B, but the response will be limited. In that respect it is tempting to use SST as an adjunct to TACE.

Finally, it would be interesting in future to see if there are additional differences between viral and alcoholic related HCC like differential expression of receptors or production of trophic factors. In a recent study an increase of serum IGF2 level was reported to be associated with the occurrence of HCC metastasis after TACE and octreotide, as metastatic foci were found in $97 \%$ when IGF2 was increasing in contrast to only $13.6 \%$ of patients with an IGF2 decrease ${ }^{[141]}$. In the context of the previous discussion, it should be noted that the expression of IGF2 in HCC was strongly associated with HBV infection ${ }^{[142]}$. 


\section{DECLARATIONS}

\section{Authors' contributions}

Devised the review, supervised the project and prepared the final draft: Kouroumalis E

Revised the clinical data and participated in the preliminary draft: Samonakis D

Revised experimental data and participated in the preliminary draft: Notas G

\section{Availability of data and materials}

Not applicable.

\section{Financial support and sponsorship}

None.

\section{Conflicts of interest}

All authors declare that there are no conflicts of interest.

\section{Ethical approval and consent to participate}

Not applicable.

\section{Consent for publication}

Not applicable.

\section{Copyright}

(C) The Author(s) 2018.

\section{REFERENCES}

1. Kim DY, Han KH. Epidemiology and surveillance of hepatocellular carcinoma. Liver Cancer 2012;1:2-14.

2. Sifaki-Pistolla D, Karageorgos SA, Koulentaki M, Samonakis D, Stratakou S, Digenakis E, Kouroumalis E. Geoepidemiology of hepatocellular carcinoma in the island of Crete, Greece. A possible role of pesticides. Liver Int 2016;36:588-94.

3. Petruzziello A. Epidemiology of hepatitis B virus (HBV) and hepatitis C virus (HCV) related hepatocellular carcinoma. Open Virol J 2018;12:26-32.

4. Krulich L, Dhariwal AP, McCann SM. Stimulatory and inhibitory effects of purified hypothalamic extracts on growth hormone release from rat pituitary in vitro. Endocrinology 1968;83:783-90.

5. Benoit R, Esch F, Bennett HP, Ling N, Ravazzola M, Orci L, Mufson EJ Processing of prosomatostatin. Metabolism 1990;39:22-5.

6. Lamberts SWJ, van der Lely AJ, de Herder WW, Hofland LJ. Octreotide. New Engl J Med 1996;334:246-54.

7. Dasgupta P. Somatostatin analogues: multiple roles in cellular proliferation, neoplasia, and angiogenesis. Pharmacol Ther 2004;102:61-85.

8. Barbieri F, Bajetto A, Pattarozzi A, Gatti M, Wurth R, Thellung S, Corsaro A, Villa V, Nizzari M, Florio T. Peptide receptor targeting in cancer: the somatostatin paradigm. Int J Pept 2013;2013:926295.

9. Patel YC. Somatostatin and its receptor family. Front Neuroendocrinol 1999;20:157-98.

10. Abdel-Rahman O, Lamarca A, Valle JW, Hubner RA. Somatostatin receptor expression in hepatocellular carcinoma: prognostic and therapeutic considerations Endocr Relat Cancer 2014;21:R485-93.

11. Bruns C,Weckbecker G, Raulf F, Kaupmann K, Schoeffter P, Lubbert H. Molecular pharmacology of somatostatin receptor subtype. Ann NY Acad Sci 1994;733:138-46.

12. Florio T, Scorizello A, Fattore M, D’Alto V, Salzano S, Rossi G, Berlingieri MT, Fusco A, Schettini G. Somatostatin inhibits PC C13 thyroid cell proliferation through the modulation of phosphotyrosine phophatase activity-impairment of the somatostatinergirc effects by stable expression of EIA viral oncogene. J Biol Chem 1996;271:6129-36.

13. Møller LN, Stidsenb CE, Hartmann B, Holst JJ. Somatostatin receptors. Biochim Biophys Acta 2003;1616:1-84.

14. Weckbecker G, Raulf F, Stolz B, Bruns C. Somatostatin analogs for diagnosis and treatment of cancer. Pharmacol Ther 1993;60:245-64.

15. Raderer M, Hejna MH, Muller C, Kornek GV, Kurtaran A, Virgolini I, Fiebieger W, Hamilton G, Scheithauer W. Treatment of hepatocellular cancer with the long acting somatostatin analog lanreotide in vitro and in vivo. Int J Oncol 2000;16:1197-201.

16. Reynaert H, Rombouts K, Vandermonde A, Urbain D, Kumar U, Bioulac- Sage P, Pinzani M, Rosenbaum J, Geerts A. Expression of somatostatin receptors in normal and cirrhotic human liver and in hepatocellular carcinoma. Gut 2004;53:1180-9.

17. Kaemmerer D, Schindler R, Mußbach F, Dahmen U, Altendorf-Hofmann A, Dirsch O, Sänger J, Schulz S, Lupp A. Somatostatin and CXCR4 chemokine receptor expression in hepatocellular and cholangiocellular carcinomas: tumor capillaries as promising targets. 
BMC Cancer 2017;17:896.

18. Notas G, Kolios G, Mastrodimou N, Kampa M, Vasilaki A, Xidakis C, Castanas E, Thermos K, Kouroumalis E. Cortistatin production by HepG2 human hepatocellular carcinoma cell line and distribution of somatostatin receptors. J Hepatol 2004;40:792-8.

19. Samonakis DN, Notas G, Christodoulakis N, Kouroumalis EA. Mechanisms of action and resistance of somatostatin analogues for the treatment of hepatocellular carcinoma: a message not well taken. Dig Dis Sci 2008;53:2359-65.

20. Siehler S, Seuwen K, Hoyer D. [125I]Tyr10-cortistatin14 labels all five somatostatin receptors. Naunyn Schmiedebergs Arch Pharmacol 1998;357:483-9.

21. Reubi JC, Waser B, Cescato R, Gloor B, Stettler C, Christ E. Internalized somatostatin receptor subtype 2 in neuroendocrine tumors of octreotidetreated patients. J Clin Endocrinol Metab 2010;95:2343-50,

22. Reynaert H, Vaeyens F, Qin H, Hellemans K, Chatterjee N, Winand D, Quartier E, Schuit F, Urbain D, Kumar U, Patel YC, Geerts A. Somatostatin suppresses endothelin-1 induced rat hepatic stellate cell contraction via somatostatin receptor subtype 1. Gastroenterology 2001;121:915-30.

23. Song SH, Leng XH, Li T, Qin ZZ, Peng JR, Zhao L, Wei YH, Yu X. Expression of subtypes of somatostatin receptors in hepatic stellate cells. World J Gastroenterol 2004;10:1663-5.

24. Klironomos S, Notas G, Sfakianaki O, Kiagiadaki F, Xidakis C, Kouroumalis E. Octreotide modulates the effects on fibrosis of TNF- $\alpha$, TGF- $\beta$ and PDGF in activated rat hepatic stellate cells. Regul Pept 2014;188:5-12.

25. Notas G, Xidakis C, Valatas V, Vasilaki A, Mastrodimou N, Manousou P, Kolios G, Thermos K, Kouroumalis E. LPS modifies the expression and accumulation of somatostatin receptors in rat Kupffer cells. J Hepatol 2005;42:232.

26. Xidakis C, Mastrodimou N, Notas N, Renieri E, Kolios G, Kouroumalis E, Thermos K. RT-PCR and immunocytochemistry studies support the presence of somatostatin, cortistatin and somatostatin receptor subtypes in rat Kupffer cells Reg Pept 2007;143:76-82.

27. Reubi JC, Zimmermann A, Jonas S, Waser B, Neuhaus P, Läderach U, Wiedenmann B. Regulatory peptide receptors in human hepatocellular carcinomas. Gut 1999;45:766-74.

28. Blaker M, Schmitz M, Gocht A, Burghardt S, Schulz M, Broring DC, Pace A, Greten H, de Weerth A. Differential expression of somatostatin receptor subtypes in hepatocellular carcinomas. J Hepatol 2004;41:112-8.

29. Xie YM, Yan LN, Wei B, Guo MM, Tang CW. Correlation of somatostatin receptor expression in human hepatocellular carcinoma tissue to serum alpha-fetoprotein concentration. Ai Zheng 2007;26:688-92. (in Chinese)

30. Verhoef C, van Dekken H, Hofland LJ, Zondervan PE, de Wilt JH, van Marion R, de Man RA, IJzermans JN, van Eijck CH. Somatostatin receptor in human hepatocellular carcinomas: biological, patient and tumor characteristics. Dig Surg 2008;25:21-6.

31. Koc EU, Ozgur T, Yerci O, Gurel S. Somatostatin receptor 1 (SSTR1) and somatostatin receptor 5 (SSTR5) expression in hepatocellular carcinoma. Hepatogastroenterology 2013;60:1693-7.

32. Chou CK, Ho LT, Ting LP, Hu CP, Su TS, Chang WC, Suen CS, Huang MY, Chang CM. Selective suppression of insulin-induced proliferation of cultured human hepatoma cells by somatostatin. J Clin Invest 1987;79:175-8.

33. Chen X, Liu Z, Ai Z. Antineoplastic mechanism of octreotide action in human hepatoma. Chin Med J 2001;114:1167-70.

34. Liu HL, Huo L, Wang L. Octreotide inhibits proliferation and induces apoptosis of hepatocellular carcinoma cells. Acta Pharmacol Sin 2004;25:1380-6.

35. Hua YP, Yin XY, Peng BG, Li SQ, Lai JM, Liang HZ, Liang LJ. Mechanisms and influence of octreotide-induced regulation of somatostatin receptor 2 on hepatocellular carcinoma. Chemotherapy 2009;55:312-20.

36. Lü XH, Wang CH, Xie Y. Differences of therapeutic efficacy between different kinds of somatostatin analogue for primary hepatocellular carcinoma. Sichuan Da Xue Xue Bao Yi Xue Ban 2017;48:549-55. (in Chinese)

37. Xie Y, Tang CW, Wang CH. Effect of HBV X gene transfection on octreotide-inhibited growth of hepatocellular carcinoma cell line HepG2. Ai Zheng 2005;24:965-9. (in Chinese)

38. Neaud V, Faouzi S, Guirouilh J, Le Bail B, Balabaud C, Bioulac-Sage P, Rosenbaum J. Human hepatic myofibroblasts increase invasiveness of hepatocellular carcinoma cells: evidence for a role of hepatocyte growth factor. Hepatology 1997;26:1458-66.

39. Theret K, Musso O, Turlin B, Lotrian D, Bioulac-Sage P, Campion JP, Boudjéma K, Clément B. Increased extracellular matrix remodeling is associated with tumor progression in human hepatocellular carcinomas. Hepatology 2001;34:82-8.

40. Pan Q, Li DG, Lu HM, Lu LY, Wang YQ, Xu QF. Antiproliferative and proapoptotic effects of somatostatin on activated hepatic stellate cells. World J Gastroenterol 2004;10:1015-8.

41. Reynaert H, Rombouts K, Jia Y, Urbain D, Chatterjee N, Uyama N, Geerts A. Somatostatin at nanomolar concentration reduces collagen I and III synthesis by, but not proliferation of activated rat hepatic stellate cells. Br J Pharmacol 2005;146:77-88.

42. Wang C, Tang C, Tang L. Inhibition effects of octreotide on the growth of hepatocellular carcinoma in vitro and in vivo. Zhonghua Yi Xue Za Zhi 2001;81:1194-7. (in Chinese)

43. Ferjoux G, Bousquet C, Cordelier P, Benali N, Lopez F, Rochaix P, Buscail L, Susini C. Signal transduction of somatostatin receptors negatively controlling cell proliferation. J Physiol Paris 2000;94:205-10.

44. Florio T, Yao H, Carey KD, Dillon TJ, Stork PJ. Somatostatin activation of mitogen-activated protein kinase via somatostatin receptor 1 (SSTR1). Mol Endocrinol 1999;13:24-37.

45. Cordelier P, Esteve JP, Bousquet C, Delesque N, Am OC, Schally AV, Vaysse N, Susini C, Buscail L. Characterization of the antiproliferative signal mediated by the somatostatin receptor subtype sst5. Proc Natl Acad Sci U S A 1997;94:9343-8.

46. Lahlou H, Saint-Laurent N, Esteve JP, Eychene A, Pradayrol L, Pyronnet S, Susini C. sst2 Somatostatin receptor inhibits cell proliferation through Ras-, Rap1-, and B-Raf-dependent ERK2 activation. J Biol Chem 2003;278:39356-71.

47. Neel BG, Tonks NK. Protein tyrosine phosphatases in signal transduction. Curr Opin Cell Biol1997;9:193-204. 
48. War SA, Kumar U. Coexpression of human somatostatin receptor-2 (SSTR2) and SSTR3 modulates antiproliferative signaling and apoptosis. J Mol Signal 2012;7:5.

49. Grant M, Alturaihi H, Jaquet P, Collier B, Kumar U. Cell growth inhibition and functioning of human somatostatin receptor type 2 are modulated by receptor heterodimerization. Mol Endocrinol 2008;22:2278-92.

50. Teijeiro R, Rios R, Costoja J, Castro R, Bello J, Devesi J, Arce V. Activation of human somatostatin receptor 2 promotes apoptosis through a mechanism that is independent from induction of p53. Cell Physiol Biochem 2002;12:31-8.

51. Lasfer M, Vadrot N, Schally AV, Nagy A, Halmos G, Pessayre D, Feldmann G, Reyl-Desmars FJ. Potent induction of apoptosis in human hepatoma cell lines by targeted cytotoxic somatostatin analogue AN-238. J Hepatol 2005;42:230-7.

52. Theodoropoulou M, Zhang J, Laupheimer S, Paez-Pereda M, Florio T Pagotto U, Stalla G. Octreotide, a somatostatin analogue, mediates its antiproliferative action in pituitary tumor cells by altering phosphatidylinositol 3-kinase signaling and inducing Zac1 expression. Cancer Res 2006;66:1576-82.

53. Tsagarakis NJ, Drygiannakis I, Batistakis AG, Kolios G, Kouroumalis EA. Octreotide induces caspase activation and apoptosis in human hepatoma HepG2 cells. World J Gastroenterol 2011;17:313-21.

54. Ma Q, Meng LQ, Liu JC, Hu JP, Ge J, Wan YL, Jiang S. Octreotide induces apoptosis of human hepatoma cells by the mechanism of facilitating the Fas/FasL gene expression therein. Zhonghua Yi Xue Za Zhi 2008;88:716-8. (in Chinese)

55. Notas G, Kampa M, Nifli AP, Xidaki C, Papasava D, Thermos K, Kouroumalis E, Castanas E. The inhibitory effect of opioids on HepG2 cells is mediated via interaction with somatostatin receptors. Eur J Pharmacol 2007;555:1-7.

56. Avella DM, Kimchi ET, Donahue RN, Tagaram RS, McLaughlin PJ, Zagon IS, Staveley-O'Carrol KF. The opioid growth factoropioid growth factor receptor axis regulates cell proliferation of human hepatocellular cancer. Am J Physiol Regul Integr Comp Physiol 2010;298:R459-66.

57. Ren SG, Ezzat S, Melmed S, Braunstein GD. Somatostatin analog induces insulin-like growth factor binding protein-1 (IGFBP-1) expression in human hepatoma cells. Endocrinology 1992;131:2479-81.

58. Scharf JG, Dombrowski F, Ramadori G. The IGF axis and hepatocarcinogenesis. Mol Pathol 2001;54:138-44.

59. Huynh H, Chow P, Ooi L, Soo K. A possible role for insulin-like growth factor binding protein-3 autocrine/paracrine loops in controlling hepatocellular carcinoma cell proliferation. Cell Growth Differ 2002;13:115-22.

60. Scharf JG, Braulke T. The role of the IGF axis in hepatocarcinogenesis. Horm Metab Res 2003;35:685-93.

61. Alexia C, Fallot G, Lasfer M, Schweizer-Groyer G, Groyer A. An evaluation of the role of insulin-like growth factors (IGF) and of type-I IGF receptor signalling in hepatocarcinogenesis and in the resistance of hepatocarcinoma cells against drug-induced apoptosis. Biochem Pharmacol 2004;68:1003-15.

62. Pivonello C, de Martino MC, Negri M, Cuomo G, Cariati F, Izzo F, Colao A, Pivonello R. The GH-IGF-SST system in hepatocellular carcinoma: biological and molecular pathogenetic mechanisms and therapeutic targets. Infect Agent Cancer 2014;9:27.

63. Hasskarl J, Kaufmann M, Schmid HA. Somatostatin receptors in non-neuroendocrine malignancies: the potential role of somatostatin analogs in solid tumors. Future Oncol 2011;7:895-913.

64. Downward J. Targeting RAS signalling pathways in cancer therapy. Nat Rev Cancer 2003;3:11-22.

65. Hwang YH, Choi JY, Kim S, Chung ES, Kim T, Koh SS, Lee B, Bae SH, Kim J, Park YM. Over-expression of c-raf-1 protooncogene in liver cirrhosis and hepatocellular carcinoma. Hepatol Res 2004;29:113-21.

66. Roberts PJ, Der CJ. Targeting the Raf-MEK-ERK mitogen-activated protein kinase cascade for the treatment of cancer. Oncogene 2007;26:3291-310.

67. Caraglia M, Tassone P, Marra M, Budillon A, Venuta S, Tagliaferri P. Targeting Raf-kinase: molecular rationales and translational issues. Ann Oncol 2006;17:124-7.

68. Bousquet C, Guillermet J, Vernejoul F, Lahlou H, Buscail L, Susini C. Somatostatin receptors and regulation of cell proliferation. Dig Liver Dis 2004;36:S2-7.

69. Adams RL, Adams IP, Lindow SW, Zhong W, Atkin SL. Somatostatin receptors 2 and 5 are preferentially expressed in proliferating endothelium. Br J Cancer 2005;92:1493-8.

70. Jia WD, Xu GL, Sun HC, Wang L, Xu RN, Xue Q. Effect of octreotide on angiogenesis induced by hepatocellular carcinoma in vivo. Hepatobiliary Pancreat Dis Int 2003;2:404-9.

71. Jia WD, Xu GL, Xu RN, Sun HC, Wang L, Yu JH, Wang J, Li JS, Zhai ZM, Xue Q. Octreotide acts as an antitumor angiogenesis compound and suppresses tumor growth in nude mice bearing human hepatocellular carcinoma xenografts. J Cancer Res Clin Oncol 2003;129:327-34.

72. Garcia de la Torre N, Wass JA, Turner HE. Antiangiogenic effects of somatostatin analogues. Clin Endocrinol 2002;57:425-41.

73. Ristori C, Ferretti ME, Pavan B, Cervellati F, Casini G, Catalani E, Dal Monte M, Biondi C. Adenylyl cyclase/cAMP system involvement in the antiangiogenic effect of somatostatin in the retina. Results from transgenic mice. Neurochem Res 2008;33:1247-55.

74. Gao JH, Wen SL, Feng S, Yang WJ, Lu YY, Tong H, Liu R, Tang SH, Huang ZY, Tang YM, Yang JH, Xie HQ, Tang CW. Celecoxib and octreotide synergistically ameliorate portal hypertension via inhibition of angiogenesis in cirrhotic rats. Angiogenesis 2016;19:501-11.

75. Lamberts SW, de Herder WW, Hofland LJ. Somatostatin analogs in the diagnosis and treatment of cancer. Trends Endocrinol Metab 2002; $13: 451-7$.

76. Lattuada D, Casnici C, Crotta K, Mastrotto C, Franco P, Schmid HA, Marelli O. Inhibitory effect of pasireotide and octreotide on lymphocyte activation. J Neuroimmunol 2007;182:153-9.

77. Dalm VASH, Hofland LJ, Lamberts SW. Future clinical prospects in somatostatin/cortistatin/somatostatin receptor field. Mol Cell Endocrinol 2008;286:262-77. 
78. Pintér E, Helyes Z, Szolcsányi J. Inhibitory effect of somatostatin on inflammation and nociception. Pharmacol Ther 2006;112:440-56

79. Chao TC, Chao HH, Chen MF, Lin JD. Somatostatin modulates the function of Kupffer cells. Reg Pept 1997;69:143-9.

80. Valatas V, Kolios G, Manoussou P, Xidakis C, Notas G, Ljumovic D, Kouroumalis EA. Secretion of inflammatory mediators by isolated rat Kupffer cells: the effect of octreotide. Reg Pept 2004;120:215-22.

81. Zhu XD, Zhang JB, Zhuang PY, Zhu HG, Zhang W, Xiong YQ, Wu WZ, Wang L, Tang ZY, Sun HC. High expression of macrophage colony-stimulating factor in peritumoral liver tissue is associated with poor survival after curative resection of hepatocellular carcinoma. J Clin Oncol 2008;26:2707-16.

82. Wan S, Kuo N, Kryczek I, Zou W, Welling TH. Myeloid cells in hepatocellular carcinoma. Hepatology 2015;62:1304-12.

83. Wan S, Zhao E, Kryczek I, Vatan L, Sadovskaya A, Ludema G, Simeone DM, Zou W, Welling TH. Tumor associated macrophages produce interleukin 6 and signal via STAT3 to promote expansion of human hepatocellular carcinoma stem cells. Gastroenterology 2014;147:1393-404.

84. Sica A, Invernizzi P, Mantovani A. Macrophage plasticity and polarizationin liver homeostasis and pathology. Hepatology 2014;59:2034-42.

85. Xidakis C, Kolios G, Valatas V, Notas G, Mouzas I, Kouroumalis E. Effect of octreotide on apoptosis-related proteins in rat Kupffer cells: a possible anti-tumour mechanism. Anticancer Res 2004;24:833-41.

86. Eggert T, Wolter K, Ji J, Ma C, Yevsa T, Klotz S, Medina-Echeverz J, Longerich T, Forgues M, Reisinger F, Heikenwalder M, Wang XW, Zender L, Greten TF. Distinct functions of senescence-associated immune responses in liver tumor surveillance and tumor progression. Cancer Cell 2016;30:533-47.

87. Li X, Yao W, Yuan Y, Chen P, Li B, Li J, Chu R, Song H, Xie D, Jiang X, Wang H. Targeting of tumour-infiltrating macrophages via CCL2/CCR2 signalling as a therapeutic strategy against hepatocellular carcinoma. Gut 2017;66:157-67.

88. Baeck C, Wei X, Bartneck M, Fech V, Heymann F, Gassler N, Hittatiya K, Eulberg D, Luedde T, Trautwein C, Tacke F. Pharmacological inhibition of the chemokine CCL2 (MCP-1) accelerates liver fibrosis regression by suppressing Ly-6C+ macrophage infiltration. Hepatology 2014;59:1060-72.

89. Valatas V, Kolios G, Manousou P, Notas G, Xidakis C, Diamantis I, Kouroumalis E. Octreotide regulates CC but not CXC LPS-induced chemokine secretion in rat Kupffer cells. Br J Pharmacol 2004;141:477-87.

90. Fujita T, Soontrapa K, Ito Y, Iwaisako K, Moniaga CS, Asagiri M, Majima M, Narumiya S. Hepatic stellate cells relay inflammation signaling from sinusoids to parenchyma in mouse models of immune-mediated hepatitis. Hepatology 2016;63:1325-39.

91. Fujita T, Narumiya S. Roles of hepatic stellate cells in liver inflammation: a new perspective. Inflamm Regen 2016;36:1.

92. Lang A, Sakhnini E, Fidder HH, Maor Y, Bar-Meir S, Chowers Y. Somatostatin inhibits pro-inflammatory cytokine secretion from rat hepatic stellate cells. Liver Int 2005;25:808-16.

93. Xidakis C, Lumovic D, Manoussou P, Notas G, Valatas V, Kolios G, Kouroumalis E. Production of pro- and anti-fibrotic agents by rat Kupffer cells: the effect of octreotide. Dig Dis Sci 2005;50:935-41.

94. Pyronnet S, Bousquet C, Najib S, Azar R, Laklai H, Susini C. Antitumor effects of somatostatin. Mol Cell Endocrinol 2008;286:230-7.

95. Shaaban S, Negm A, Ibrahim EE, Elrazak AA. Chemotherapeutic agents for the treatment of hepatocellular carcinoma: efficacy and mode of action. Oncol Rev 2014;8:246.

96. Schindel DT, Grosfeld JL. Hepatic resection enhances growth of residual intrahepatic and subcutaneous hepatoma, which is inhibited by octreotide. J Pediatr Surg 1997;32:995-7.

97. Papalampros E, Felekouras ES, Filis K, Angelopoulou R, Kourelis T, Tsamandas AC, Bastounis E. Liver pathology and cell proliferation after octreotide administration following partial hepatectomy in rats: an experimental study. Dig Dis Sci 2002;47:1953-8.

98. Hua YP, Huang JF, Liang LJ, Li SQ, Lai JM, Liang HZ. The study of inhibition effect of octreotide on the growth of hepatocellular carcinoma xenografts in situ in nude mice. Zhonghua Wai Ke Za Zhi 2005;43:721-5. (in Chinese)

99. Jia WD, Xu GL, Wang W, Wang ZH, Li JS, Ma JL, Ren WH, Ge YS, Yu JH, Liu WB. A somatostatin analogue, octreotide, inhibits the occurrence of second primary tumors and lung metastasis after resection of hepatocellular carcinoma in mice. Tohoku J Exp Med 2009;218:155-60.

100. Xie Y, Chen S, Wang C, Tang C. SOM230 combined with celecoxib prolongs survival in nude mice with HepG-2 xenografts. Cancer Biol Ther 2011;12:86-92.

101. Tong H, Li X, Zhang CL, Gao JH, Wen SL, Huang ZY, Wen FQ, Fu P, Tang CW. Transcatheter arterial embolization followed by octreotide and celecoxib synergistically prolongs survival of rabbits with hepatic VX2 allografts. J Dig Dis 2013;14:29-37.

102. Tong H, Li X, Zhang CL, Gao JH, Wen SL, Huang ZY, Tang CW. Octreotide and celecoxib synergistically encapsulate VX2 hepatic allografts following transcatheter arterial embolisation. Exp Ther Med 2013;5:777-82.

103. Borbath I, Leclercq IA, Abarca-Quinones J, Desaeger C, Lebrun V, Moulin P, Sempoux C, Horsmans Y. Inhibition of early preneoplastic events in the rat liver by the somatostatin analog lanreotide. Cancer Sci 2007;98:1831-9.

104. Borbath I, Leclercq IA, Sempoux C, Abarca-Quinones J, Desaege C, Horsmans Y. Efficacy of lanreotide in preventing the occurrence of chemically induced hepatocellular carcinoma in rats. Chem Biol Interact 2010;183:238-48.

105. Borbath I, Stärkel P. Chemoprevention of hepatocellular carcinoma. Proof of concept in animal models. Acta Gastroenterol Belg 2011;74:34-44.

106. Abdel-Hamid NM, Mohafez OM, Nazmy MH, Farhan A, Thabet K. The effect of co-administration of Lawsonia inermis extract and octreotide on experimental hepatocellular carcinoma. Environ Health Prev Med 2015;20:195-203.

107. Wang XX, Ye T, Li M, Li X, Qiang O, Tang CW, Liu R. Effects of octreotide on hepatic glycogenesis in rats with high fat dietinduced obesity. Mol Med Rep 2017;16:109-18. 
108. Kouroumalis E, Skordilis P, Thermos K, Vasilaki A, Moschandrea J, Manousos ON. Treatment of hepatocellular carcinoma with octreotide: a randomised controlled study. Gut 1998;42:442-7.

109. Samonakis DN, Moschandreas J, Arnaoutis T, Skordilis P, Leontidis C, Vafiades I, Kouroumalis E. Treatment of hepatocellular carcinoma with long acting somatostatin analogues. Oncol Rep 2002;9:903-7.

110. Patsanas T, Kapetanos D, Ilias A, Gessiou Ch, Tzarou V, Kokozidis G, Kitis G. Octreotide in the treatment of inoperable hepatocellular carcinoma. Ann Gastroenterol 2004;17:69-74.

111. Dimitroulopoulos D, Xinopoulos D, Tsamakidis K, Zisimopoulos A, Andriotis E, Panagiotakos D, Fotopoulou A, Chrysohoou C, Bazinis A, Daskalopoulou D, Paraskevas E. Long acting octreotide in the treatment of advanced hepatocellular cancer and overexpression of somatostatin receptors: randomized placebo-controlled trial. World J Gastroenterol 2007;13:3164-70.

112. Pan DY, Qiao JG, Chen JW, Huo YC, Zhou YK, Shi HA. Tamoxifen combined with octreotide or regular chemotherapeutic agents in treatment of primary liver cancer: a randomized controlled trial. Hepatobiliary Pancreat Dis Int 2003;2:211-5.

113. Gill ML, Atiq M, Sattar S, Khokhar N. Treatment outcomes with long acting octreotide in inoperable hepatocellular carcinoma: a local experience and review of literature. J Pak Med Assoc 2005;55:135-8.

114. Shah U, O’Neil B, Allen J, Goldberg RM, Bernard S, Moore D, Venook AP, Morse MM. A phase II study of long-acting octreotide in patients with advanced hepatocellular carcinoma and CLIP score of 3 or higher. Gastrointest Cancer Res 2009;3:45-8.

115. Schöniger-Hekele M, Kettenbach J, Peck-Radosavljevic M, Müller C. Octreotide treatment of patients with hepatocellular carcinoma--a retrospective single centre controlled study. J Exp Clin Cancer Res 2009;28:142.

116. Raderer M, Hejna MH, Kurtaran A, Kornek GV, Valencak JB, Oberhuber G, Vorbeck F, Virgolini I, Scheithauer W. Successful treatment of an advanced hepatocellular carcinoma with the long-acting somatostatin analog lanreotide. Am J Gastroenterol 1999;94:278-9.

117. Siveke J, Folwaczny C, Herberhold C. Complete regression of advanced HCC with long acting octreotide. Gut 2003;52:1531.

118. Borbath I, Lhommel R, Guiot Y, Coche E, Sempoux C. Lanreotide treatment of metastatic hepatocellular carcinoma resulting in partial regression and more than 3 years of progression-free survival. Acta Gastroenterologica Belgica 2012;75:270-3.

119. Treiber G, Wex T, Rocken C, Fostitsch P, Malfertheiner P. Impact of biomarkers on disease survival and progression in patients treated with octreotide for advanced hepatocellular carcinoma. J Cancer Res Clin Oncol 2006;132:699-708.

120. Li S, Liu Y, Shen Z. Characterization of somatostatin receptor 2 and 5 expression in operable hepatocellular carcinomas. Hepatogastroenterology 2012;59:2054-8.

121. Liu Y, Jiang L, Mu Y. Somatostatin receptor subtypes 2 and 5 are associated with better survival in operable hepatitis B-related hepatocellular carcinoma following octreotide long-acting release treatment. Oncology Lett 2013;6:821-8.

122. Plentz RR, Tillmann HL, Kubicka S, Bleck JS, Gebel M, Manns MP, Rudolph KL. Hepatocellular carcinoma and octreotide: treatment results in prospectively assigned patients with advanced tumor and cirrhosis stage. J Gastroenterol Hepatol 2005;20:1422-8.

123. Montella L, Addeo R, Caraglia M, Faiola V, Guarrasi R, Vincenzi B, Palmeri A, Capasso E, Nocera V, Tarantino L, Ariete M, Martorelli A, Del Prete S. Vascular endothelial growth factor monitoring in advanced hepatocellular carcinoma patients treated with radiofrequency ablation plus octreotide: a single center experience. Oncol Rep 2008;20:385-90.

124. Jia W, Feng K, Fan P, Fan G, Yang S, Zhang T, Wei Q, Qian L. Post-TACE combination therapy of heparin and octreotide results in decreased tumor metastasis in extrahepatic tumorigenesis. Cell Biochem Biophys 2012;62:35-40.

125. Tong H, Wei B, Chen S, Xie YM, Zhang MG, Zhang LH, Huang ZH, Tang CW. Adjuvant celecoxib and lanreotide following transarterial chemoembolisation for unresectable hepatocellular carcinoma: a randomized pilot study. Oncotarget 2017;8:48303-12.

126. Prete SD, Montella L, Caraglia M, Maiorino L, Cennamo G, Montesarchio V, Piai G, Febbraro A, Tarantino L, Capasso E, Palmieri G, Guarrasi R, Bianco M, Mamone R, Savastano C, Pisano A, Vincenzi B, Sabia A, D’Agostino A, Faiola V, Addeo R. Sorafenib plus octreotide is an effective and safe treatment in advanced hepatocellular carcinoma: multicenter phase II So.LAR study. Cancer Chemother Pharmacol 2010;66:837-44.

127. Caraglia M, Giuberti G, Marra M, Addeo R, Montella L, Murolo M, Sperlongano P, Vincenzi B, Naviglio B, Del Prete S, Abbruzzese A, Stiuso P. Oxidative stress and ERK1/2 phosphorylation as predictors of outcome in hepatocellular carcinoma patients treated with sorafenib plus octreotide LAR. Cell Death Dis 2011;2:e150.

128. Rabe C, Pilz T, Allgaier HP, Halm U, Strasser C, Wettstein M, Sauerbruch T, Caselmann WH. Clinical outcome of a cohort of 63 patients with hepatocellular carcinoma treated with octreotide. Z Gastroenterol 2002;40:395-400.

129. Yuen MF, Poon RT, Lai CL, Fan ST, Lo CM, Wong KW, Wong WM, Wong BC. A randomized placebo-controlled study of long-acting octreotide for treatment of advanced hepatocellular carcinoma. Hepatology 2002;36:687-91.

130. Kouroumalis E, Samonakis D, Sordilis P. Octreotide treatment of hepatocellular carcinoma. Hepatology 2003;37:477.

131. Slijkhuis WA, Stadheim L, Hassoun ZM, Nzeako UC, Kremers WK, Talwalkar JA, Gores GJ. Octreotide therapy for advanced hepatocellular carcinoma. J Clin Gastroenterol 2005;39:333-8.

132. Samonakis DN, Christodoulakis N, Kouroumalis EA. Octreotide for unresectable hepatocellular carcinoma: beyond the first sight. J Clin Gastroenterol 2006;40:86-7.

133. Cebon J, Findlay M, Hargreaves C, Stockler M, Thompson P, Boyer M, Roberts S, Poon A, Scott AM, Kalff V, Garas G, Dowling A, Crawford D, Ring J, Basser R, Strickland A, Macdonald G, Green M, Nowak A, Dickman B, Dhillon H, Gebski V; Australasian Gastrointestinal Trials group (AGITG) and Ag0001H Investigators. Somatostatin receptor expression, tumour response, and quality of life in patients with advanced hepatocellular carcinoma treated with long-acting octreotide. Br J Cancer 2006;95:853-61.

134. Verset G, Verslype C, Reynaert H, Borbath I, Langlet P, Vandebroek A, Peeters M, Houbiers G, Francque S, Arvanitakis Van Laethem JL. Efficacy of the combination of long-acting release octreotide and tamoxifen in patients with advanced hepatocellular carcinoma: a randomised multicentre phase III study. Br J Cancer 2007;97:582-8. 
135. Becker G, Allgaier HP, Olschewski M, Zahringer A, Blum HE; HECTOR Study Group. Long-acting octreotide versus placebo for treatment of advanced HCC: a randomized controlled double-blind study. Hepatology 2007;45:9-15.

136. Barbare JC, Bouché O, Bonnetain F, Dahan L, Lombard-Bohas C, Faroux R, Raoul JL, Cattan S, Lemoine A, Blanc JF, Bronowicki JP, Zarski JP, Cazorla S, Gargot D, Thevenot T, Diaz E, Bastie A, Aparicio T, Bedenne L. Treatment of advanced hepatocellular carcinoma with long-acting octreotide: a phase III multicentre, randomised, double blind placebo-controlled study. Eur J Cancer 2009;45:1788-97.

137. Sanoff HK, Kim R, Ivanova A, Alistar A, McRee AJ, O’Neil BH. Everolimus and pasireotide for advanced and metastatic hepatocellular carcinoma. Invest New Drugs 2015;33:505-9.

138. Feun LG, Wangpaichitr M, Li YY, Kwon D, Richman SP, Hosein PJ, Savaraj N. Phase II trial of SOM230 (pasireotide LAR) in patients with unresectable hepatocellular carcinoma. J Hepatocell Carcinoma 2018;5:9-15.

139. Ji XQ, Ruan XJ, Chen H, Chen G, Li SH, Yu B. Somatostatin analogues in advanced hepatocellular carcinoma: an updated systematic review and meta-analysis of randomized controlled trials. Med Sci Monit 2011;17:RA169-76.

140. Bruix J, Sherman M; American Association for the Study of Liver Diseases. Management of hepatocellular carcinoma: an update. Hepatology 2011;53:1020-2.

141. Xiong ZP, Huang F, Lu MH. Association between insulin-like growth factor-2 expression and prognosis after transcatheter arterial chemoembolization and octreotide in patients with hepatocellar carcinoma. Asian Pacific J Cancer Prev 2012;13:3191-4.

142. Qian J, Yao D, Dong Z, Wu W, Qiu L, Yao N, Li S, Bian Y, Wang Z, Shi G. Characteristics of hepatic IGF-II expression and monitored levels of circulating IGF-II mRNA in metastasis of hepatocellular carcinoma. Am J Clin Pathol 2010;134:799-806. 